ABSENCE OF

FORMALDEHYDE-INDUCED

NeOPLASIA IN TRP53

HAPLOINSUfFICIENT MICE

EXPOSED BY INHALATION

NTP RR 3

AUGUST 2017 


\title{
NTP Research Report on Absence of Formaldehyde-Induced Neoplasia in Trp53 Haploinsufficient Mice Exposed by Inhalation
}

\author{
Research Report 3 \\ National Toxicology Program
}

August 2017

Toxicology Branch

Division of the National Toxicology Program

National Institute of Environmental Health Sciences

ISSN: 2473-4756 
Absence of Formaldehyde-Induced Neoplasia in Trp53 Haploinsufficient Mice Exposed by Inhalation

\section{Table of Contents}

Tables ii

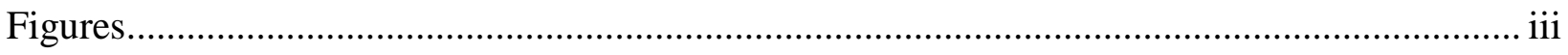

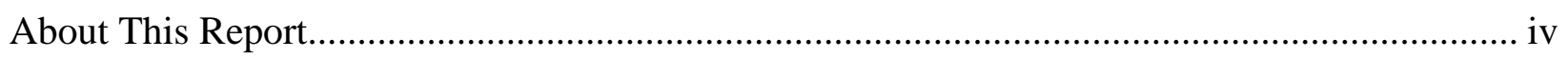

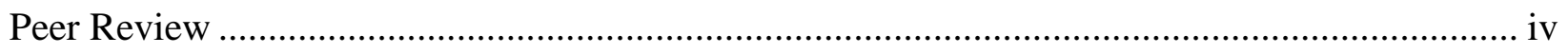

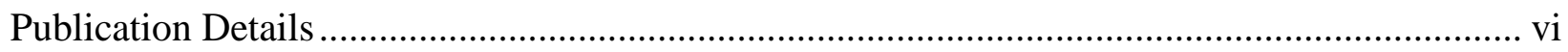

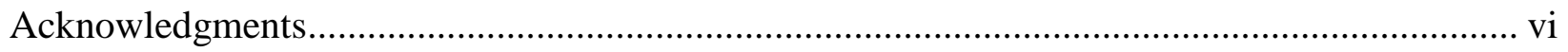

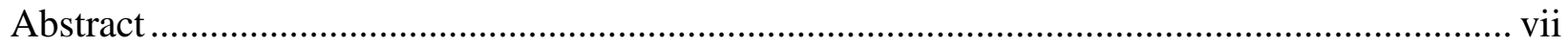

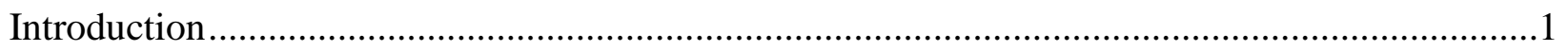

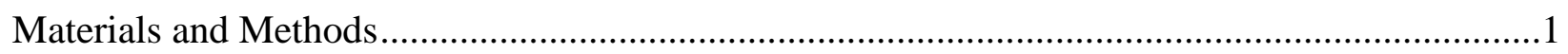

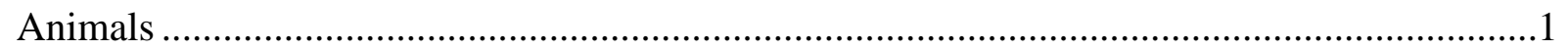

Formaldehyde Generation and Monitoring ................................................................

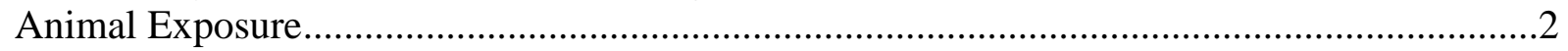

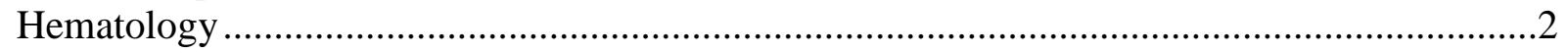

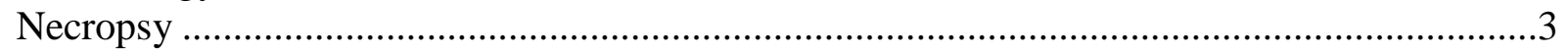

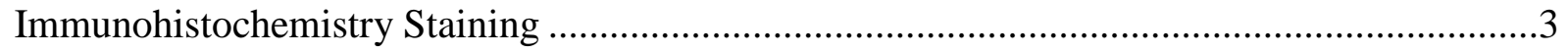

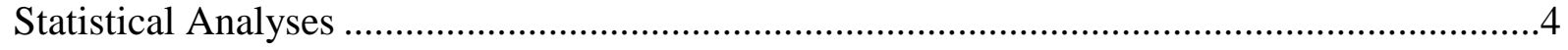

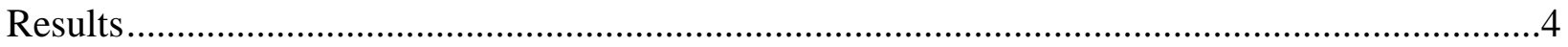

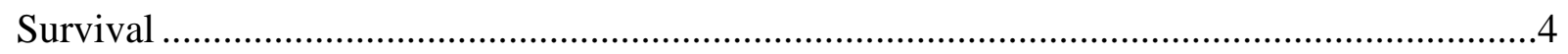

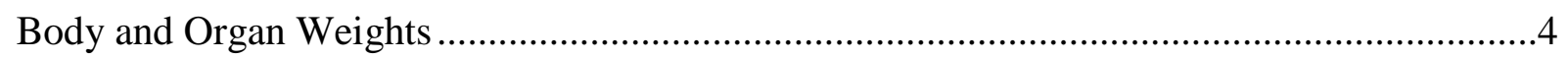

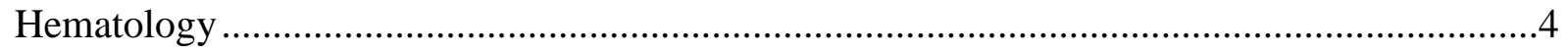

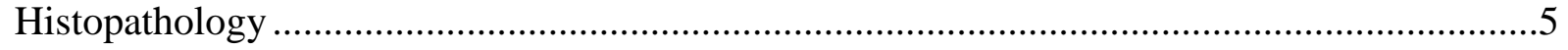

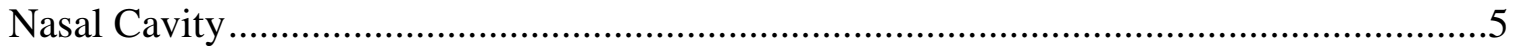

Neoplasms in C3B6.129F1-Trp53 ${ }^{\mathrm{tm1Brd}}$ Mice............................................................

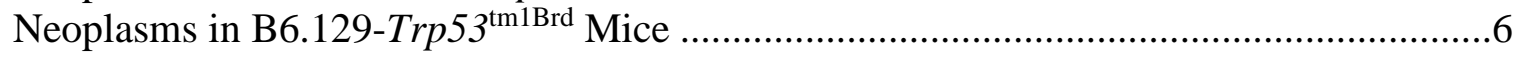

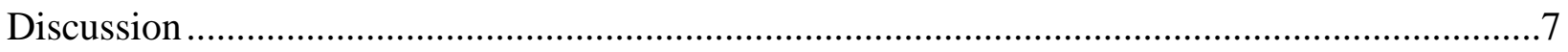

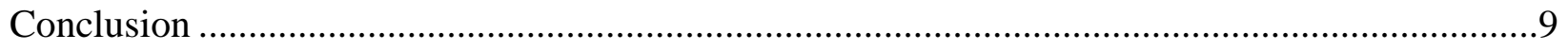

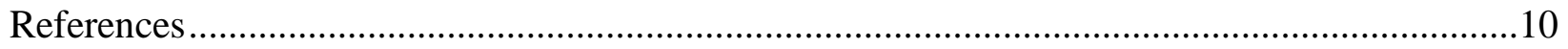

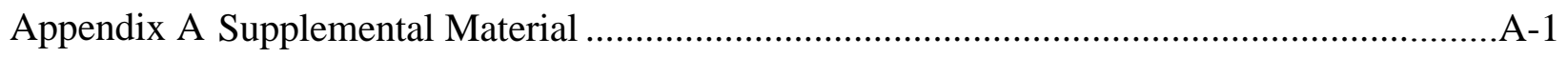

\section{Tables}

Table 1. Mortality in Trp53 ${ }^{+}$Mice Exposed to Formaldehyde.................................................14

Table 2. Hematological Parameters of C3B6.129F1-Trp53 ${ }^{\text {tm1Brd }}$ Mice Exposed to

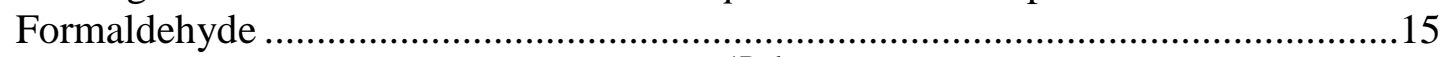

Table 3. Hematological Parameters of B6.129-Trp53 ${ }^{\text {tm1Brd }}$ Mice Exposed to

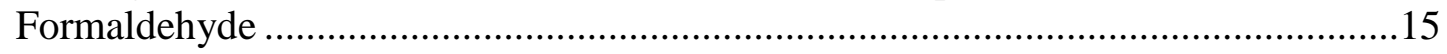

Table 4. Nasal Lesions in Trp53 ${ }^{+}$Mice Exposed to Formaldehyde ............................................16

Table 5. Neoplasms in C3B6.129F1-Trp53 ${ }^{\text {tm1Brd }}$ Mice Exposed to Formaldehyde ......................16 
Absence of Formaldehyde-Induced Neoplasia in Trp53 Haploinsufficient Mice Exposed by Inhalation

Table 6. Neoplasms in B6.129-Trp53 ${ }^{\text {tm1Brd }}$ Mice Exposed to Formaldehyde

\section{Figures}

Figure 1. Body Weights of Trp53 $3^{+}$Mice Exposed to Formaldehyde 18

Figure 2. Squamous Metaplasia of the Nasal Cavity in Mice Exposed to Formaldehyde.

Figure 3. Keratin Accumulation and Osteogenesis in Nasal Cavity of Mice Exposed to

Formaldehyde

Figure 4. Neoplastic Lesions in Trp53 $3^{+}$Mice Exposed to Formaldehyde.

Figure A-1. Thymus, Cortex, Lymphoma of C3B6.129F1-Trp53 ${ }^{\text {tm1Brd }}$ Mice Exposed to Formaldehyde.

*This report has been reformatted to meet new NTP publishing requirements; its content has not changed. 
Absence of Formaldehyde-Induced Neoplasia in Trp53 Haploinsufficient Mice Exposed by Inhalation

\section{About This Report}

\section{Authors}

Daniel L. Morgan ${ }^{1}$, Darlene Dixon ${ }^{1}$, Debra H. King ${ }^{1}$, Greg S. Travlos ${ }^{1}$, Ronald A. Herbert ${ }^{1}$, John E. French ${ }^{1}$, Erik J. Tokar ${ }^{1}$, Michael P. Waalkes ${ }^{1}$, Michael P. Jokinen ${ }^{2}$

${ }^{1}$ Division of the National Toxicology Program, National Institute of Environmental Health

Sciences, Research Triangle Park, North Carolina, USA

${ }^{2}$ Integrated Laboratory Systems, Research Triangle Park, North Carolina, USA

Division of the National Toxicology Program, National Institute of Environmental Health Sciences, Research Triangle Park, North Carolina, USA

Daniel L. Morgan, Ph.D.

Darlene Dixon, Ph.D., D.V.M.

Debra H. King

Greg S. Travlos, D.V.M., D.A.C.V.P.

Ronald A. Herbert, Ph.D., D.V.M.

John E. French, Ph.D.

Erik J. Tokar, Ph.D.

Michael P. Waalkes, Ph.D.

Integrated Laboratory Systems, Research Triangle Park, North Carolina, USA

Michael P. Jokinen, D.V.M.

\section{Peer Review}

The draft research report on the study of formaldehyde exposure to T53 haploinsufficient mice was evaluated by the reviewers listed below. These reviewers served as independent scientists, not as representatives of any institution, company, or governmental agency. In this capacity, reviewers determined if the design and conditions of these NTP studies were appropriate and ensured that this NTP Research Report presented the experimental results and conclusions fully and clearly.

\section{Peer Reviewers}

\section{Terry Gordon, Ph.D.}

Professor

Department of Environmental Medicine

School of Medicine

New York University

New York, New York

Dennis W. Wilson, Ph.D., D.V.M.

Professor Emeritus of Pathology

Department of Pathology, Microbiology, and Immunology 
Absence of Formaldehyde-Induced Neoplasia in Trp53 Haploinsufficient Mice Exposed by Inhalation

School of Veterinary Medicine

University of California

Davis, California 
Absence of Formaldehyde-Induced Neoplasia in Trp53 Haploinsufficient Mice Exposed by Inhalation

\section{Publication Details}

Publisher: National Toxicology Program

Publishing Location: Research Triangle Park, North Carolina

ISSN: 2473-4756

DOI: https://doi.org/10.22427/NTP-RR-3

Report Series: NTP Research Report Series

Report Series Number: 3

Official Citation: Morgan, DL, Dixon, D, King, DH, Travlos, GS, Herbert, RA, French, JE, Tokar, EJ, Waalkes, MP, Jokinen, MP. 2017. NTP Research Report on Absence of

Formaldehyde-Induced Neoplasia in Trp53 Haploinsufficient Mice Exposed by Inhalation. NTP

RR 3. Research Triangle Park, NC: National Toxicology Program (3): 1-29.

\section{Acknowledgments}

This research was supported by the Intramural Research Program of the NIH National Institute of Environmental Health Sciences. These studies were conducted at the NIEHS Inhalation Facility under contract to Alion Science and Technology, Inc. The authors thank Dr. Grace Kissling for statistical analysis and Drs. Michelle Hooth and Gordon Flake for critical review of this manuscript. 
Absence of Formaldehyde-Induced Neoplasia in Trp53 Haploinsufficient Mice Exposed by Inhalation

\begin{abstract}
Formaldehyde inhalation is linked to nasal cancer and leukemia in humans. Formaldehydeinduced DNA-protein crosslinks and enhanced cell proliferation are important in the pathogenesis of nasal cancer and, potentially, leukemia. Mutations in the tumor suppressor gene Trp53 have been associated with formaldehyde-induced nasal tumors and might be a key mechanistic event in formaldehyde-induced leukemia. The objective of this study was to evaluate the potential role of the Trp53 gene in formaldehyde-induced nasal carcinogenicity, leukemia or lymphohematopoietic cancer, and potentially other neoplasms in genetically susceptible mice. Male Trp53 haploinsufficient (Trp53 $3^{ \pm}$) mouse strains (B6.129-Trp53 ${ }^{\mathrm{tm} 1 \mathrm{Brd}}$ and C3B6.129F1-Trp53 ${ }^{\mathrm{tm} 1 \mathrm{Brd}}$ ) were exposed to 0-, 7.5- or 15-ppm formaldehyde (25/group) $6 \mathrm{~h} / \mathrm{d}$, $5 \mathrm{~d} / \mathrm{wk}$ for $8 \mathrm{wk}$, and then held for $32 \mathrm{wk}$. Blood was collected for hematology, and major tissues and gross lesions were collected for histopathology. The primary formaldehyde-related finding was squamous metaplasia of the respiratory epithelium of the nose. Inhalation of a maximum tolerated dose of formaldehyde caused significant injury to the nasal mucosa and cell proliferation, but did not cause nasal tumors or an increased prevalence of leukemia or lymphohematopoietic cancer in $\operatorname{Tr} 55^{ \pm}$mice. All observed neoplasms were considered background lesions for these mouse strains. The results of this short-term carcinogenicity study do not support a role for Trp53 in formaldehyde-induced neoplasia.
\end{abstract}

Key Words: formaldehyde, Trp53 mutations, $\operatorname{Tr} 553^{ \pm}$mice, nasal cavity, neoplasia, inhalation 
Absence of Formaldehyde-Induced Neoplasia in Trp53 Haploinsufficient Mice Exposed by Inhalation

\section{Introduction}

Formaldehyde is recognized as a nasal carcinogen in humans ${ }^{1}$ and laboratory rats ${ }^{2-4}$. Exposure of rats to formaldehyde results in development of squamous cell carcinoma (SCC) in the anterior and posterior lateral meatus of the nasal cavity ${ }^{2}$. DNA-protein crosslinks (DPC) and cell proliferation are prominent at sites of SCC formation in the rat nasal cavity ${ }^{4-6}$, suggesting that incomplete repair of DPC results in mutations within the proliferating cell population and might lead to neoplasia. Considerable evidence shows that formaldehyde-induced mutations in the tumor suppressor gene Trp53 are important in the pathogenesis of nasal cancer ${ }^{7 ; 8}$. Mutations in Trp53 were identified in formaldehyde-induced nasal SCC in rats ${ }^{9}$, and abnormal Trp53 protein was shown to accumulate in the nasal tissue of formaldehyde-exposed rats ${ }^{10}$. Mutations in $\operatorname{Trp53}$ result in loss of tumor suppression functions including RNA repair, cell cycle arrest, senescence, and apoptosis ${ }^{11}$, resulting in a loss of normal growth control and clonal expansion of mutated cells ${ }^{12-14}$.

Formaldehyde also has been reported to cause myeloid leukemia in humans ${ }^{15}$, although the mechanism is unknown. Mutations in the Trp53 gene could be important in the pathogenesis of leukemia or lymphohematopoietic cancer. Zhang et al. ${ }^{16}$ proposed that hematopoietic stem cells in the nasal epithelium or in circulation undergo formaldehyde-induced mutations that result in loss of Trp53 and acquisition of the capacity for self-renewal. The Trp53 gene is involved in regulating the self-renewal of hematopoietic stem cells ${ }^{17-20}$. In addition, disruption of the Trp53 pathway has been shown to enhance production of induced pluripotent stem cells capable of selfrenewal $^{21}$. Acquisition of self-renewal capacity is one of the initial steps in cancer development $^{22}$. Formaldehyde-induced loss of Trp53 would be rare, however, and indeed an increased incidence of lymphohematopoietic cancer has not been observed in formaldehydeexposed wild type rats and mice ${ }^{3}$.

Currently no good animal model is available for investigating the mechanism(s) by which formaldehyde causes leukemia. Because considerable evidence suggests a role of Trp53 in formaldehyde-induced nasal SCC, we evaluated two Trp53-haploinsufficient (Trp53) mouse strains in this study. We hypothesized that formaldehyde-induced loss of Trp53 would be increased in $\operatorname{Trp53}^{+}$mice, resulting in an increased incidence of SCC of the nose and leukemia or lymphohematopoietic cancer, and potentially neoplasms at other sites.

\section{Materials and Methods}

\section{Animals}

Two mouse strains heterozygous for the null and wildtype Trp53 allele were used to evaluate the potential role of Trp53 in formaldehyde-induced lymphohematopoietic cancer. The inbred B6.129-Trp53 ${ }^{\text {tm1Brd }}$ (Model P53N12-M) mouse strain was selected for this study because of its previous use as a model for lymphohematopoietic tumors in short-term cancer bioassays ${ }^{23-29}$. The C3B6.129F1-Trp53 ${ }^{\text {tm1Brd }}$ strain also was selected based on the observation of chemical exposuredependent lymphohematopoietic tumors of either lymphoid- or myeloid-committed stem cell origin $^{30 ; 31}$. This strain is an outcross between C3H/HeNTac female (Model C3H-F) xB6.129Trp53 ${ }^{\mathrm{tm} 1 B r d}$ (Model P53N12-M) homozygous Trp53 null allele male to produce the haploinsufficient F1 progeny. Heterozygotes were selected because they have a lower 
background incidence of sporadic tumors than the homozygotes, and the latency for sporadically occurring tumors is longer than in the homozygotes ${ }^{32 ; 33}$. Although rats appear to be more susceptible than mice to formaldehyde-induced SCC of the nose, a genetically modified rat strain was not available at the time of this study.

Male C3B6.129F1-Trp53 ${ }^{\text {tm1Brd }}$ mice were 9 weeks old on arrival and male B6.129-Trp53 ${ }^{\text {tm1Brd }}$ haploinsufficient mice (Taconic, Hudson, NY) were 8-10 weeks old on arrival. After a 3- (B6.129-Trp53 ${ }^{\mathrm{tm} 1 \mathrm{Brd}}$ ) to 4-week (C3B6.129F1-Trp53 ${ }^{\mathrm{tm} 1 \mathrm{Brd}}$ ) quarantine period, mice were weighed and randomly assigned to three exposure groups (Table 1). Five mice per strain were assigned to sentinel groups. All mice were acclimated to the Hazleton 2000 exposure chambers for 3 days prior to exposure. Food (NIH-31) was removed during the 6-hour exposure periods; and water was always available. Body weights were recorded weekly.

\section{Formaldehyde Generation and Monitoring}

Nominal chamber concentrations of 7.5-ppm and 15-ppm formaldehyde vapor were generated by heating paraformaldehyde. These concentrations were selected based on reports in the literature and on the results of a 2-week range-finding study in mice. Because cell proliferation plays a key role in formaldehyde-induced neoplasia, exposure concentrations were selected that caused significant injury and cell regeneration in the nasal cavity in the range-finding study. Two 1-liter Woulff bottles containing 200 grams of prilled paraformaldehyde (Sigma Aldrich, St. Louis, MO) were heated on hot plates to $95^{\circ} \mathrm{C}$ (7.5 ppm) and $120^{\circ} \mathrm{C}$ (15 ppm). A constant volume (1 liter per minute [LPM]) of breathing-quality air (dried, filtered, and carbon-scrubbed) was delivered to the Woulff bottles. A metered volume of the formaldehyde-enriched headspace was mixed with the chamber supply air stream (500-LPM humidified, filtered, and carbon-scrubbed air). The Hazleton 2000 exposure chamber concentrations were monitored using a Model Z-300XP Formaldehyde Monitor (Environmental Sensors, Boca Raton, FL).

\section{Animal Exposure}

Mice were individually housed in Hazleton 2000 chambers and exposed to either conditioned air (charcoal and HEPA filtered, temperature and humidity controlled) or to 7.5- or 15-ppm formaldehyde in conditioned air 6 hours/day, 5 days/week, for 8 weeks. This treatment regimen represents a standard 5-day workweek, used for studying chemicals for which exposure is primarily occupational. Exposures of the two strains were staggered by 1 week because of the large numbers of mice to be necropsied. The exposure of the B6.129-Trp53 ${ }^{\mathrm{tm} 1 \mathrm{Brd}}$ mice began 1 week after beginning the exposure of C3B6.129F1-Trp53 ${ }^{\mathrm{tm} 1 \mathrm{Brd}}$ mice. Following the 8-week inhalation exposures, mice were transferred to individual polycarbonate cages and monitored for 32 weeks (until 51-53 weeks of age). Mice were weighed and examined for gross lesions weekly. Mice with large or ulcerated tumors were euthanized and a necropsy conducted.

\section{Hematology}

On the day of the scheduled necropsy, whole blood samples were collected under isoflurane anesthesia by means of the retro-orbital venous sinus into tubes containing $\mathrm{K}_{2}$ EDTA as anticoagulant. The whole blood was analyzed for a complete blood count (CBC) evaluation. CBC endpoints, including absolute leukocyte (total and differential), erythrocyte (red blood cell $[\mathrm{RBC}])$, reticulocyte (\% and absolute [Retics]) and platelet (Plt) counts, hemoglobin (HgB) 
concentrations and hematocrit (Hct), mean corpuscular volume (MCV), mean corpuscular hemoglobin $(\mathrm{MCH})$, and mean corpuscular hemoglobin concentration (MCHC) values, were obtained using the ProCyte Dx hematology analyzer (IDEXX Laboratories, Westbrook, ME). A packed cell volume (spun hematocrit) was performed using an Autocrit Ultra 3 micro-hematocrit centrifuge (Becton, Dickinson and Company, Franklin Lakes, NJ). Microscopic evaluation of Romanowsky-stained blood smears was performed to assess leukocyte differential distribution percentages and RBC, WBC, and Plt morphology.

\section{Necropsy}

Mice found moribund during the study and those that survived to the end of the study were euthanized by $\mathrm{CO}_{2}$ asphyxiation and exsanguination. At necropsy, major organs were weighed and the following tissues, including gross lesions, were collected for pathology evaluations. The distal 1-2 cm of the left femur was sectioned through the frontal plane to include the articular cartilage and articular surface, the femoral condyles with epiphyseal plate, and diaphysis with bone marrow. The left femur was fixed in 10\% neutral-buffered formalin (NBF). The nasal cavities were fixed by retrograde infusion of NBF, and then immersed in NBF. The formalinfixed nasal cavities were decalcified (RDO Rapid Decalcifier; Apex Engineering Products, Aurora, IL) for 12 hours. After decalcification, three separate sections of the nasal cavity were taken at (1) the level of the incisor teeth (Level 1), (2) midway between incisors and first molar (Level 2), and (3) middle of second molar (olfactory region) (Level 3). The remainder of the nasal cavity and turbinates were carefully examined for gross lesions. One-half of the trachea was left attached to the lung. After weighing the lung, the trachea was used to inflate the lungs with fixative. The lungs were trimmed to allow the largest cross-section surface area possible. A transverse section of the larynx was taken at the base of the epiglottis just anterior to the laryngeal saccule. Two sections of liver including transverse sections through the left and median lobes were taken midway along the greatest dimension. A section of gallbladder was included in the section of median lobe. A mid-longitudinal section (left kidney) and a cross section (right kidney) through the entire cortex, pelvis, and medulla of each kidney were collected. Mesenteric, mandibular, mediastinal, and bronchial lymph nodes were collected and placed in cassettes. After formalin fixation, tissues were trimmed and processed, embedded in paraffin wax, sectioned at $5 \mu \mathrm{m}$, and stained with hematoxylin and eosin (H\&E). A pathologist evaluated the slides, and then the tumor slides were reviewed by four additional pathologists during a Pathology Peer Review.

\section{Immunohistochemistry Staining}

Immunohistochemistry was used to better characterize sarcomas. Formalin-fixed, paraffinembedded tissue sections were deparaffinized in xylene and rehydrated through graded alcohols. Heat-induced antigen retrieval in citrate buffer ( $\mathrm{pH}$ 6.0, Biocare Medical, Concord, CA) was done in a Decloaker ${ }^{\circledR}$ pressure chamber for 5 minutes at $110{ }^{\circ} \mathrm{C}$, followed by $3 \%$ hydrogen peroxide for 15 minutes to quench endogenous peroxidase activity. Nonspecific sites were blocked by incubating slides for 20 minutes with 2.5\% normal horse serum (Vector, Burlingame, $\mathrm{CA}$ ). The sections then were then incubated with rabbit monoclonal antimyogenin antibody (Cat\# ab124800, Lot\# GR155521-1, Abcam, Cambridge, MA) at 1:500 dilution, or a rabbit monoclonal anti-vimentin antibody (Cat\# ab92547, lot\# GR145336-12, Abcam) at 1:1000 dilution for 1 hour at room temperature. For negative control tissue sections, normal rabbit IgG 
Absence of Formaldehyde-Induced Neoplasia in Trp53 Haploinsufficient Mice Exposed by Inhalation

(Calbiochem ${ }^{\circledR}$, San Diego, CA), diluted to match the protein concentration of the myogenin or vimentin antibodies, was utilized. The antigen-antibody complex was detected using ImmPRESS HRP anti-rabbit IgG (Vector) and 3,3-diaminobenzidine (Dako, Carpinteria, CA). Slides were then counterstained with hematoxylin, dehydrated, and cover-slipped. The myogenin slides were stained manually, whereas the vimentin slides were stained via a Biocare Intellipath ${ }^{\mathrm{TM}}$ FLX autostainer (Biocare Medical).

\section{Statistical Analyses}

Cochran-Armitage trend tests were used to test for dose-related trends in incidences of neoplasms. Fisher's exact tests (one-sided) were used to compare incidences of neoplasms between each dose group and the control group. Hematology data were analyzed using nonparametric multiple comparison methods ${ }^{34 ; 35}$.

\section{Results}

\section{Survival}

Nine C3B6F1.129-Trp53 ${ }^{\text {tm1Brd }}$ animals died prior to the scheduled sacrifice (Table 1). Sixty-five animals of this strain survived to study termination. Sixteen B6.129-Trp53 ${ }^{\mathrm{tm} 1 \mathrm{Brd}}$ animals died prior to the time of scheduled sacrifice (Table 1). Most of these animals were euthanized early due to the presence of large, grossly visible tumors. Seventy-five B6.129-Trp53 ${ }^{\mathrm{tm} 1 \mathrm{Brd}}$ animals survived to study termination.

\section{Body and Organ Weights}

Body weights of C3B6F1.129-Trp53 ${ }^{\mathrm{tm} 1 \mathrm{Brd}}$ mice exposed to 7.5-ppm formaldehyde were significantly less than controls ( $\mathrm{p}<0.05)$ from week 1 to week 11, and at weeks 37 and 38 . Body weights of mice exposed to 15-ppm formaldehyde were significantly less than controls $(\mathrm{p}<0.05)$ from week 1 to week 24, and at weeks 37 and 38 (Figure 1). Absolute and relative liver weights were significantly decreased $11 \%$ and $8 \%$, respectively, in mice exposed to 15-ppm formaldehyde. Lung, kidney, spleen, and thymus weights of formaldehyde-exposed mice were not significantly different from controls (data not shown).

Body weights of B6.129-Trp53 ${ }^{\mathrm{tm} 1 \mathrm{Brd}}$ mice exposed to formaldehyde were not significantly different from controls at any time point (Figure 1). Absolute and relative liver, lung, kidney, spleen, and thymus weights of formaldehyde-exposed B6.129-Trp53 ${ }^{\text {tm1Brd }}$ mice were not significantly different from controls (data not shown).

\section{Hematology}

Hematological parameters for formaldehyde-exposed C3B6F1.129-Trp53 ${ }^{\text {tm1Brd }}$ (Table 2) and B6.129-Trp53 ${ }^{\text {tm1Brd }}$ (Table 3) mice were not significantly different from their respective controls. Neither strain showed any indication of treatment-related hematotoxicity, leukemia, or lymphoma. 
Absence of Formaldehyde-Induced Neoplasia in Trp53 Haploinsufficient Mice Exposed by Inhalation

\section{Histopathology}

\section{Nasal Cavity}

Formaldehyde exposure-related non-neoplastic lesions were observed primarily in the nasal cavity of C3B6F1.129-Trp53 ${ }^{\mathrm{tm} 1 \mathrm{Brd}}$ and B6.129-Trp53 ${ }^{\mathrm{tm} 1 \mathrm{Brd}}$ mice. These nasal lesions were quantitatively and qualitatively similar in both strains. Nasal cavity lesions considered related to formaldehyde exposure are summarized in Table 4. The number of animals examined per group includes the early-death animals.

The only nasal cavity lesion observed in the control C3B6F1.129-Trp53 ${ }^{\mathrm{tm} 1 \mathrm{Brd}}$ and B6.129Trp53 ${ }^{\text {tm1Brd }}$ animals was minimal hyaline degeneration of the respiratory epithelium, consisting of one or more small foci of epithelial cells containing intra-cytoplasmic accumulation of brightly stained eosinophilic material. This minimal lesion, observed in many of the control animals, is considered a spontaneous background finding.

Squamous metaplasia of the respiratory epithelium was observed in the nasal cavity of many C3B6F1.129-Trp53 ${ }^{\text {tm1Brd }}$ and B6.129-Trp53 ${ }^{\text {tm1Brd }}$ mice exposed to 7.5- and 15-ppm formaldehyde. The incidence and average severity (minimal to mild) of squamous metaplasia were greater in the 15-ppm group animals as compared with the 7.5-ppm animals (Table 4). Squamous metaplasia was observed consistently in Level 1, presumably because this level of the nose was exposed to the highest concentration of formaldehyde, and occasionally in Level 2, especially in the 15-ppm exposure groups (Figure 2). This lesion was not observed in Level 3. Squamous metaplasia was observed most commonly on the medial surface of the maxilloturbinates, facing the nasal septum. Other affected sites included the lateral wall, tips of the nasoturbinates, and, occasionally, the dorsal surface of the dorsal meatus. Squamous metaplasia was characterized microscopically by areas of replacement of the normal respiratory epithelium by a thin to occasionally moderately thick layer of stratified squamous epithelium. In some cases, the squamous epithelium was quite thin and was recognized as squamous epithelium by the presence of a layer of thin, laterally flattened cells on the epithelial surface typical of squamous epithelium. Often, a thin to moderately thick layer of keratin, sometimes containing cell debris, was present on the epithelial surface of turbinates in exposed (Figure 3B) but not control (Figure 3A) mice. In a few noses, accumulated keratin was present in the space behind a turbinate scroll, and in some cases filled the space behind the scroll (Figure 3C).

Osteogenesis, proliferation of new bone, was observed in the turbinate bone in a few C3B6.129F1-Trp53 ${ }^{\mathrm{tm} 1 \mathrm{Brd}}$ and B6.129-Trp53 ${ }^{\mathrm{tm} 1 \mathrm{Brd}}$ animals exposed to formaldehyde (Table 4). Microscopically, the osteogenesis had a similar appearance in the two strains and in each animal consisted of a small focus of proliferating bone within the lamina propria of the affected turbinate characterized by eosinophilic osteoid containing numerous large plump osteoblast nuclei (Figure 3D).

\section{Neoplasms in C3B6.129F1-Trp53 ${ }^{\text {tm1Brd }}$ Mice}

Several neoplasms were observed in control and formaldehyde-exposed C3B6.129F1-Trp53 ${ }^{\text {tm1Brd }}$ mice, and none was considered caused by formaldehyde exposure (Table 5). Three lymphomas were found in the early-death C3B6.129F1-Trp53 ${ }^{\text {tm1Brd }}$ animals: one in the 7.5-ppm group involving the thymus and two lymph nodes, and the remaining two in the 15-ppm group 
involving only the thymus. No lymphomas were observed in the control group. The incidences of lymphoma in the formaldehyde-treated groups were not statistically significant $(\mathrm{p}>0.05)$ relative to controls. The lymphomas all had a typical and similar morphological appearance, and consisted of diffuse sheets of relatively large lymphocytes with large, moderately pleomorphic basophilic, granular nuclei with one or more prominent nucleoli and a scant amount of eosinophilic cytoplasm (Figure A-1).

Five osteosarcomas were found in bone and skeletal muscle of C3B6.129F1-Trp53 ${ }^{\text {tm1Brd }}$ mice (Table 5). Osteosarcomas were present in two scheduled sacrifice animals (one control and one 7.5-ppm animal), and both had metastasized to the lung. The three remaining osteosarcomas occurred in the early-death control animals. Microscopically, the osteosarcomas were discrete masses composed of irregular intersecting trabeculae of eosinophilic osteoid, the matrix material for bone, admixed with variable numbers of highly pleomorphic neoplastic spindle-shaped cells (Figure 4A). Although osteosarcomas are considered to originate from bone, three osteosarcomas (from the early-death control animals) had skeletal muscle attached to them but no bone. We assumed they had originated in bone and had invaded adjacent skeletal muscle, but that the bony origins of these neoplasms were not included in the microscopic sections. Osteosarcomas stained positively for vimentin, an intermediate filament typically present in cytoplasm of non-epithelial cells (Figure 4B), and stained negatively for smooth muscle actin, myogenin, and F4/80.

In addition to osteosarcomas, an undifferentiated sarcoma was also observed in the skeletal muscle of a 7.5-ppm C3B6.129F1-Trp53 ${ }^{\mathrm{tm} 1 \mathrm{Brd}}$ animal. This neoplasm was a large, discrete mass consisting of numerous large, round to ovoid to elongated cells with abundant eosinophilic cytoplasm and small basophilic nuclei. Hepatocellular adenoma and carcinoma, histiocytic sarcoma, and hemangiosarcoma also were observed in some animals, but the incidences were not significantly increased or concentration related (Table 5).

Osteosarcomas in two control mice and a hemangiosarcoma in one 7.5-ppm animal were in contact with or had enveloped the microchip transponders used for animal identification. Sarcomas, osteosarcomas, and histiocytic sarcoma in eight C3B6.129F1-Trp53 ${ }^{\text {tm1Brd }}$ animals were located remotely from the microchips.

\section{Neoplasms in B6.129-Trp53 ${ }^{\text {tm1Brd }}$ Mice}

A variety of observed neoplasms in formaldehyde-exposed B6.129-Trp53 ${ }^{\mathrm{tm} 1 \mathrm{Brd}}$ mice were not considered chemical related (Table 6). Lymphomas were present in two formaldehyde-exposed B6.129-Trp53 ${ }^{\text {tm1Brd }}$ animals, one in the 7.5-ppm group and one in the 15-ppm group. The lymphoma in the 7.5-ppm animal, which appeared to have originated in the thymus, had spread widely, being present in nearly every tissue examined. In contrast, the lymphoma in the 15-ppm animal appeared to have originated in the mesenteric lymph node with a small amount of involvement of the bronchial lymph node. The lymphomas appeared morphologically similar to one another and to the lymphomas observed in the C3B6.129F1-Trp53 ${ }^{\text {tm1Brd }}$ animals (Figure A-1).

Skeletal muscle rhabdomyosarcomas were observed in five formaldehyde-exposed B6.129Trp53 $3^{\mathrm{tm} 1 \mathrm{Brd}}$ animals, one in the 7.5-ppm group and four in the 15-ppm group (includes early death animals) (Table 6). Rhabdomyosarcomas were not observed in B6.129-Trp53 ${ }^{\text {tm1Brd }}$ control animals. Although a statistically significant trend $(p=0.042)$ was found, the incidence of 
rhabdomyosarcomas in the 15-ppm group was not statistically significant $(p=0.133)$ relative to controls. Microscopically, the neoplasms were large masses composed of solid foci and interlacing bands of neoplastic cells generally admixed with varying amounts of dense fibrous tissue stroma (Figure 4C). The neoplasms were composed primarily of variably sized pleomorphic polygonal to fusiform cells, with large ovoid to fusiform, moderately basophilic to vesicular nuclei with one to several prominent nucleoli and small to moderate and occasionally large amounts of eosinophilic cytoplasm with indistinct borders. Few to numerous mitotic figures were present, and varying numbers of large multinucleated cells resembling rhabdomyoblasts were observed. Cross striations were not observed; however, the tumors stained positively for vimentin, a marker for cells of mesenchymal origin including skeletal muscle, and myogenin, a nuclear transcription factor essential for skeletal muscle development and repair, and a specific marker for skeletal muscle (Figure 4D).

Various other neoplasms occurred at low incidences in control and formaldehyde-exposed B6.129-Trp53 ${ }^{\text {tm1Brd }}$ animals, all of which were considered background lesions unrelated to formaldehyde exposure (Table 6). Microchip transponders were found in contact with, or enveloped by, tumors in five B6.129-Trp53 ${ }^{\mathrm{tm} 1 \mathrm{Brd}}$ animals exposed to formaldehyde. Sarcomas in 10 B6.129-Trp53 ${ }^{\text {tm1Brd }}$ animals were not associated with microchip transponders.

\section{Discussion}

Formaldehyde-induced injury to the nasal epithelium, regenerative proliferation, and mutations in these proliferating cells are key steps in the pathogenesis of formaldehyde-induced nasal SCC $^{4 ; 6}$. Mutations in the tumor suppressor gene Trp53 have been detected in formaldehydeinduced nasal tumors and in preneoplastic hyperkeratotic plaques, indicating that Trp53 mutations are involved in the pathogenesis of $\mathrm{SCC}^{9 ; 10}$. Based on these data, Trp53 ${ }^{ \pm}$mice were expected to be highly susceptible to formaldehyde-induced nasal SCC, and possibly leukemia and other neoplasms. Under the conditions of this short-term study, however, formaldehyde exposure did not result in SCC of the nasal cavity or in an increased incidence of leukemia or lymphohematopoietic neoplasms in two genetically susceptible Trp53 mouse strains. Formaldehyde-induced loss heterozygosity (LOH) in Trp53 and loss of tumor suppressor function may have been insufficient to induce neoplasia. Although mutations to Trp53 can result in a dysfunctional protein, some mutations to Trp53 can result in a gain of function (GOF) that promotes tumor development ${ }^{36 ; 37}$. Formaldehyde-induced mutations of Trp53 that result in GOF may be necessary for induction of neoplasia.

Although rats are more susceptible than mice to formaldehyde-induced nasal tumors ${ }^{3}$, a $\operatorname{Trp53}{ }^{+}$ rat strain was not available at the time of this study. Mice are reportedly less susceptible than rats because of their greater ability to reduce their minute ventilation upon repeated formaldehyde exposures $^{38 ;} 39$, thereby reducing tissue damage and cell turnover in the nasal mucosa.

Spontaneous SCC of the nasal cavity is extremely rare in rats and mice. Tumors of the nasal cavity have not been observed in NTP historical controls for B6C3F1/N or B6.129-Trp53 ${ }^{\text {tm1Brd }}$ mice. Background nasal tumor incidences for the C3B6.129F1-Trp53 ${ }^{\mathrm{tm} 1 \mathrm{Brd}}$ were not available. Induction of SCC in wild type mice by formaldehyde is also extremely rare. Exposure of C57BL/6 x C3HF1 mice to 14.3-ppm formaldehyde for 2 years followed by a 6-month holding period resulted in only two mice with nasal tumors ${ }^{3}$. 
In this study, mice were exposed to concentrations of formaldehyde that caused significant cell injury, inflammation, and regeneration in the nasal mucosa, which are recognized as key events in nasal SCC development ${ }^{5}$. Although significant regenerative cell proliferation and squamous metaplasia were observed in exposed mice, a higher formaldehyde concentration, a longer exposure duration, or a longer holding period might be necessary for accumulation of genetic alterations in Trp53 and development of SCC in mice. The severity of nasal lesions in both mouse strains, the significantly reduced body weights of C3B6.129F1-Trp53 ${ }^{\mathrm{tm} 1 \mathrm{Brd}}$ mice, and the lack of body weight gain in both strains, however, indicated that exposure to $15 \mathrm{ppm}$ for 8 weeks represented a maximum tolerated dose. An 8-week exposure duration was considered sufficient because the doubling time for hematopoietic stem cells is reported to be between 2 and 4 weeks with the entire hematopoietic stem cell pool turning over every 8 weeks ${ }^{40 ; 41}$. Although exposed mice could have been held longer, 50 weeks of age was selected because, at approximately 70 weeks of age, about one-half of $\operatorname{Trp53^{\pm }}$ mice reportedly develop background tumors ${ }^{33}$.

Formaldehyde exposure did not significantly increase the incidence of leukemia or lymphohematopoietic neoplasms in either B6.129-Trp53 ${ }^{\mathrm{tm} 1 \mathrm{Brd}}$ or C3B6.129F1-Trp53 ${ }^{\mathrm{tm} 1 \mathrm{Brd}}$ mice. The formaldehyde exposure concentrations were observed to cause disruption of the nasal epithelium, potentially allowing exposure of the underlying nasal cavity stem cells and circulating hematopoietic stem cells in the nasal vasculature. Maximal exposure of stem cells would be expected to occur following disruption (ulceration, necrosis) of the epithelium. As noted in this study, however, the accessibility of the nasal stem cells to inhaled formaldehyde could decrease as the damaged nasal epithelium is rapidly replaced by the more resistant squamous epithelium. In addition, the squamous epithelium produced multiple layers of keratin that might also protect underlying cells from inhaled formaldehyde. Whether a similar phenomenon occurs in exposed rats is unclear. Lymphoma was observed in several formaldehyde-exposed mice and was absent in control groups for both mouse strains. The low incidence of lymphoma in formaldehyde-exposed mice, however, was not statistically significant. Lymphoma was not considered exposure related because of the low incidence, the lack of statistical significance, and because lymphoma is one of the most common spontaneous tumors reported in $\operatorname{Tr} 553^{ \pm}$mice $^{32 ; 42}$.

Sarcomas were the most prevalent tumor observed in B6.129-Trp53 ${ }^{\mathrm{tm} 1 \mathrm{Brd}}$ mice and were the most common cause of early death due to the rapid growth of these tumors. The use of subcutaneous microchip transponders for animal identification might have influenced the incidence of sarcomas in B6.129-Trp53 ${ }^{\mathrm{tm} 1 \mathrm{Brd}}$. Sarcomas can occur in B6.129-Trp53 ${ }^{\mathrm{tm} 1 \mathrm{Brd}}$ mice in association with subcutaneous microchips but can also occur spontaneously and in reaction to other treatments ${ }^{43}$. Although the mechanism for a synergistic or additive effect of subcutaneous microchip implantation and formaldehyde exposure on skeletal muscle sarcoma development in B6.129-Trp53 ${ }^{\text {tm1Brd }}$ is not clear, evidence is insufficient to rule out such an effect.

Osteosarcoma was a common spontaneous lesion in C3B6.129F1-Trp53 ${ }^{\text {tm1Brd }}$ mice, occurring in about $15 \%$ of controls and in only one animal exposed to formaldehyde (7.5 ppm).

Osteosarcomas are generally uncommon neoplasms in mice but appear to be more common in Trp53 \pm mice. Microchips were found within or in contact with tumors in two of the four control mice with osteosarcoma, and in one mouse in the 7.5-ppm group, the microchip was in contact with a hemangiosarcoma. As noted with the skeletal muscle sarcomas in B6.129-Trp53 ${ }^{\mathrm{tm} 1 \mathrm{Brd}}$ mice, immunostaining of osteosarcomas associated with, or remote from, microchips showed no differences. 
Absence of Formaldehyde-Induced Neoplasia in Trp53 Haploinsufficient Mice Exposed by Inhalation

\section{Conclusion}

Under the conditions of this study, inhalation exposure to a maximum tolerated dose of formaldehyde did not cause an increased incidence of nasal SCC, leukemia, or lymphohematopoietic tumors in Trp53 $3^{ \pm}$mice. Both mouse strains developed a variety of neoplasms, but all were considered spontaneous background lesions and not a result of formaldehyde exposure. The results of this short-term carcinogenicity study do not support a role for Trp53 in formaldehyde-induced neoplasia. 
Absence of Formaldehyde-Induced Neoplasia in Trp53 Haploinsufficient Mice Exposed by Inhalation

\section{References}

1. IARC Working Group on the Evaluation of Carcinogenic Risks to Humans Formaldehyde, 2butoxyethanol and 1-tert-butoxypropan-2-ol. IARC Monogr Eval Carcinog Risks Hum. 2006; 88:1-478. IARC Monogr Eval Carcinog Risks Hum.

2. Morgan KT, Jiang XZ, Starr TB, Kerns WD More precise localization of nasal tumors associated with chronic exposure of F-344 rats to formaldehyde gas. Toxicol Appl Pharmacol. 1986; 82(2):264-271. Toxicology and Applied Pharmacology. http://dx.doi.org/10.1016/0041$\underline{008 X(86) 90201-2}$

3. Kerns WD, Pavkov KL, Donofrio DJ, Gralla EJ, Swenberg JA Carcinogenicity of formaldehyde in rats and mice after long-term inhalation exposure. Cancer Res. 1983; 43(9):4382-4392. Cancer Research.

4. Monticello TM, Swenberg JA, Gross EA, Leininger JR, Kimbell JS, Seilkop S, Starr TB, Gibson JE, Morgan KT Correlation of regional and nonlinear formaldehyde-induced nasal cancer with proliferating populations of cells. Cancer Res. 1996; 56(5):1012-1022. Cancer Research.

5. Woutersen RA, van Garderen-Hoetmer A, Bruijntjes JP, Zwart A, Feron VJ Nasal tumours in rats after severe injury to the nasal mucosa and prolonged exposure to $10 \mathrm{ppm}$ formaldehyde. $\mathrm{J}$ Appl Toxicol. 1989; 9(1):39-46. J Appl Toxicol. http://dx.doi.org/10.1002/jat.2550090108

6. Monticello TM, Morgan KT Chemically-induced nasal carcinogenesis and epithelial cell proliferation: a brief review. Mutat Res. 1997; 380(1-2):33-41. Mutation Research. http://dx.doi.org/10.1016/S0027-5107(97)00125-5

7. Shaham J, Bomstein Y, Gurvich R, Rashkovsky M, Kaufman Z DNA-protein crosslinks and p53 protein expression in relation to occupational exposure to formaldehyde. Occup Environ Med. 2003; 60(6):403-409. Occup Environ Med. http://dx.doi.org/10.1136/oem.60.6.403

8. Recio L Oncogene and tumor suppressor gene alterations in nasal tumors. Mutat Res. 1997; 380(1-2):27-31. Mutation Research. http://dx.doi.org/10.1016/S0027-5107(97)00124-3

9. Recio L, Sisk S, Pluta L, Bermudez E, Gross EA, Chen Z, Morgan K, Walker C p53 mutations in formaldehyde-induced nasal squamous cell carcinomas in rats. Cancer Res. 1992; 52(21):6113-6116. Cancer Research.

10. Wolf DC, Gross EA, Lyght O, Bermudez E, Recio L, Morgan KT Immunohistochemical localization of p53, PCNA, and TGF-alpha proteins in formaldehyde-induced rat nasal squamous cell carcinomas. Toxicol Appl Pharmacol. 1995; 132(1):27-35. Toxicology and Applied Pharmacology. http://dx.doi.org/10.1006/taap.1995.1083

11. Brosh R, Rotter V When mutants gain new powers: news from the mutant p53 field. Nat Rev Cancer. 2009; 9(10):701-713. Nat Rev Cancer. http://dx.doi.org/10.1038/nrc2693

12. Kastan MB, Kuerbitz SJ Control of G1 arrest after DNA damage. Environ Health Perspect. 1993; 101 Suppl 5:55-58. Environ Health Perspect. 
Absence of Formaldehyde-Induced Neoplasia in Trp53 Haploinsufficient Mice Exposed by Inhalation

13. Lane DP Cancer. A death in the life of p53. Nature. 1993; 362(6423):786-787. Nature. http://dx.doi.org/10.1038/362786a0

14. Mercer WE, Shields MT, Lin D, Appella E, Ullrich SJ Growth suppression induced by wildtype p53 protein is accompanied by selective down-regulation of proliferating-cell nuclear antigen expression. Proc Natl Acad Sci U S A. 1991; 88(5):1958-1962. Proc Natl Acad Sci U S A. http://dx.doi.org/10.1073/pnas.88.5.1958

15. NTP NTP 12th Report on Carcinogens. Rep Carcinog. 2011; 12:iii-499. Rep Carcinog.

16. Zhang L, Steinmaus C, Eastmond DA, Xin XK, Smith MT Formaldehyde exposure and leukemia: a new meta-analysis and potential mechanisms. Mutat Res. 2009; 681(2-3):150-168. Mutation Research. http://dx.doi.org/10.1016/j.mrrev.2008.07.002

17. Cicalese A, Bonizzi G, Pasi CE, Faretta M, Ronzoni S, Giulini B, Brisken C, Minucci S, Di Fiore PP, Pelicci PG The tumor suppressor p53 regulates polarity of self-renewing divisions in mammary stem cells. Cell. 2009; 138(6):1083-1095. Cell.

http://dx.doi.org/10.1016/j.cell.2009.06.048

18. Liu YR, Zhou Y, Qiu W, Zeng JY, Shen LL, Li AP, Zhou JW Exposure to formaldehyde induces heritable DNA mutations in mice. J Toxicol Environ Health A. 2009; 72(11-12):767773. J Toxicol Environ Health A. http://dx.doi.org/10.1080/15287390902841615

19. Meletis K, Wirta V, Hede SM, Nister M, Lundeberg J, Frisen J p53 suppresses the selfrenewal of adult neural stem cells. Development. 2006; 133(2):363-369. Development. http://dx.doi.org/10.1242/dev.02208

20. Passegue E, Weisman IL Leukemic stem cells: where do they come from? Stem Cell Rev. 2005; 1(3):181-188. Stem Cell Rev. http://dx.doi.org/10.1385/SCR:1:3:181

21. Hong H, Takahashi K, Ichisaka T, Aoi T, Kanagawa O, Nakagawa M, Okita K, Yamanaka S Suppression of induced pluripotent stem cell generation by the p53-p21 pathway. Nature. 2009; 460(7259):1132-1135. Nature. http://dx.doi.org/10.1038/nature08235

22. Levine AJ, Momand J, Finlay CA The p53 tumour suppressor gene. Nature. 1991; 351(6326):453-456. Nature. http://dx.doi.org/10.1038/351453a0

23. NTP NTP report on the toxicology studies of aspartame (CAS No. 22839-47-0) in genetically modified (FVB Tg.AC hemizygous) and B6.129-Cdkn2atm1Rdp (N2) deficient mice and carcinogenicity studies of aspartame in genetically modified [B6.129-Trp53tm1Brd (N5) haploinsufficient] mice (feed studies). Natl Toxicol Program Genet Modif Model Rep. 2005; (1):1-222. Natl Toxicol Program Genet Modif Model Rep.

24. NTP NTP toxicology studies of acesulfame potassium (CAS No. 55589-62-3) in genetically modified (FVB Tg.AC Hemizygous) mice and carcinogenicity studies of acesulfame potassium in genetically modified [B6.129-Trp53(tm1Brd) (N5) Haploinsufficient] mice (feed studies)mice. Natl Toxicol Program Genet Modif Model Rep. 2005; (2):1-113. Natl Toxicol Program Genet Modif Model Rep.

25. NTP Toxicology studies of sodium bromate (CAS No. 7789-38-0) in genetically modified (FVB Tg.AC Hemizygous) mice (dermal and drinking water studies) and carcinogenicity studies 
Absence of Formaldehyde-Induced Neoplasia in Trp53 Haploinsufficient Mice Exposed by Inhalation

of sodium bromate in genetically modified [B6.129-Trp53tm1Brd (N5) haploinsufficient] mice (drinking water studies). Natl Toxicol Program Genet Modif Model Rep. 2007; (6):1-169. Natl Toxicol Program Genet Modif Model Rep.

26. NTP NTP report on the toxicology studies of dichloroacetic acid (CAS No. 79-43-6) in genetically modified (FVB Tg.AC hemizygous) mice (dermal and drinking water studies) and carcinogenicity studies of dichloroacetic acid in genetically modified [B6.129-Trp53(tm1Brd) (N5) haploinsufficient] mice (drinking water studies). Natl Toxicol Program Genet Modif Model Rep. 2007; (11):1-168. Natl Toxicol Program Genet Modif Model Rep.

27. NTP NTP report on the toxicology studies of dicyclohexylcarbodiimide (CAS No. 538-75-0) in F344/N rats, B6C3F 1 mice, and genetically modified (FVB Tg.AC hemizygous) mice and carcinogenicity study of dicyclohexylcarbodiimide in genetically modified [B6.129-Trp53 tm1Brd (N5) haploinsufficient] mice (dermal studies). Natl Toxicol Program Genet Modif Model Rep. 2007; (9):1-138. Natl Toxicol Program Genet Modif Model Rep.

28. NTP Toxicology studies of bromodichloromethane (CAS No. 75-27-4) in genetically modified (FVB Tg.AC Hemizygous) mice (dermal, drinking water, and gavage studies) and carcinogenicity studies of bromodichloromethane in genetically modified [B6.129Trp53(tm1Brd) (N5) haploinsufficient] mice (drinking water and gavage studies). Natl Toxicol Program Genet Modif Model Rep. 2007; (5):1-227. Natl Toxicol Program Genet Modif Model Rep.

29. NTP Toxicology studies of allyl bromide (CAS No. 106-95-6) in genetically modified (FVB Tg.AC hemizygous) mice and carcinogenicity studies of allyl bromide in genetically modified [B6.129-Trp53tm1Brd (N5) Haploinsufficient] mice (dermal and gavage studies). Natl Toxicol Program Genet Modif Model Rep. 2008; (7):1-122. Natl Toxicol Program Genet Modif Model Rep.

30. NTP Toxicology and Carcinogenesis Studies of Mixtures of 3'-Azido-3'-Deoxythymidine (AZT), Lamivudine (3TC), and Nevirapine (NVP) (CAS Nos. 30516-87-1, 134678-17-4, 129618-40-2) in Genetically Modified C3B6.129F1-Trp53(tm1Brd) N12 Haploinsufficient Mice (in utero and postnatal gavage studies). Natl Toxicol Program Genet Modif Model Rep. 2013; (16):1-236. Natl Toxicol Program Genet Modif Model Rep.

31. NTP Toxicology study of senna (CAS No. 8013-11-4) in C57BL/6NTAC Mice and toxicology and carcinogenesis study of senna in genetically modified C3B6.129F1/TacTrp53tm1Brd haploinsufficient mice (Feed Studies). Natl Toxicol Program Genet Modif Model Rep. 2012; (15):1-114. Natl Toxicol Program Genet Modif Model Rep.

32. Donehower LA, Harvey M, Slagle BL, McArthur MJ, Montgomery CA, Jr., Butel JS, Bradley A Mice deficient for p53 are developmentally normal but susceptible to spontaneous tumours. Nature. 1992; 356(6366):215-221. Nature. http://dx.doi.org/10.1038/356215a0

33. Donehower LA The p53-deficient mouse: a model for basic and applied cancer studies. Semin Cancer Biol. 1996; 7(5):269-278. Seminars in Cancer Biology. http://dx.doi.org/10.1006/scbi.1996.0035

34. Shirley E A non-parametric equivalent of Williams' test for contrasting increasing dose levels of a treatment. Biometrics. 1977; 33(2):386-389. Biometrics. http://dx.doi.org/10.2307/2529789 
Absence of Formaldehyde-Induced Neoplasia in Trp53 Haploinsufficient Mice Exposed by Inhalation

35. Dunn OJ Multiple comparisons using rank sums. Technometrics. 1964; 6:241-252. http://dx.doi.org/10.1080/00401706.1964.10490181

36. Dittmer D, Pati S, Zambetti G, Chu S, Teresky AK, Moore M, Finlay C, Levine AJ Gain of function mutations in p53. Nat Genet. 1993; 4(1):42-46. Nature Genetics.

http://dx.doi.org/10.1038/ng0593-42

37. Acin S, Li Z, Mejia O, Roop DR, El-Naggar AK, Caulin C Gain-of-function mutant p53 but not p53 deletion promotes head and neck cancer progression in response to oncogenic K-ras. J Pathol. 2011; 225(4):479-489. J Pathol. http://dx.doi.org/10.1002/path.2971

38. Chang JC, Gross EA, Swenberg JA, Barrow CS Nasal cavity deposition, histopathology, and cell proliferation after single or repeated formaldehyde exposures in B6C3F1 mice and F-344 rats. Toxicol Appl Pharmacol. 1983; 68(2):161-176. Toxicology and Applied Pharmacology. http://dx.doi.org/10.1016/0041-008X(83)90001-7

39. Chang JC, Steinhagen WH, Barrow CS Effect of single or repeated formaldehyde exposure on minute volume of B6C3F1 mice and F-344 rats. Toxicol Appl Pharmacol. 1981; 61(3):451459. Toxicology and Applied Pharmacology. http://dx.doi.org/10.1016/0041-008X(81)90368-9

40. Domen $\mathrm{J}$ The role of apoptosis in regulating hematopoietic stem cell numbers. Apoptosis. 2001; 6(4):239-252. Apoptosis : an international journal on programmed cell death. http://dx.doi.org/10.1023/A:1011347623402

41. Wilson A, Laurenti E, Oser G, van der Wath RC, Blanco-Bose W, Jaworski M, Offner S, Dunant CF, Eshkind L, Bockamp E et al. Hematopoietic stem cells reversibly switch from dormancy to self-renewal during homeostasis and repair. Cell. 2008; 135(6):1118-1129. Cell. http://dx.doi.org/10.1016/j.cell.2008.10.048

42. Harvey M, McArthur MJ, Montgomery CA, Jr., Butel JS, Bradley A, Donehower LA Spontaneous and carcinogen-induced tumorigenesis in p53-deficient mice. Nat Genet. 1993; 5(3):225-229. Nature Genetics. http://dx.doi.org/10.1038/ng1193-225

43. Storer RD, French JE, Haseman J, Hajian G, LeGrand EK, Long GG, Mixson LA, Ochoa R, Sagartz JE, Soper KA P53+/- hemizygous knockout mouse: overview of available data. Toxicol Pathol. 2001; 29 Suppl:30-50. Toxicologic Pathology.

http://dx.doi.org/10.1080/019262301753178465 
Absence of Formaldehyde-Induced Neoplasia in Trp53 Haploinsufficient Mice Exposed by Inhalation

Table 1. Mortality in Trp53 \pm Mice Exposed to Formaldehyde

\begin{tabular}{|c|c|c|c|}
\hline Formaldehyde Concentration & 0 ppm & 7.5 ppm & 15 ppm \\
\hline \multicolumn{4}{|c|}{ C3B6.129F1-Trp53 ${ }^{\mathrm{tm1Brd}}$ Mice } \\
\hline Animals/group: & 25 & 24 & 25 \\
\hline Early Deaths: & $4(16 \%)$ & $3(11 \%)$ & $2(8 \%)$ \\
\hline \multicolumn{4}{|l|}{ Cause of Death: } \\
\hline Lymphoma & 0 & 1 & 2 \\
\hline Osteosarcoma & 3 & 0 & 0 \\
\hline Sarcoma & 0 & 1 & 0 \\
\hline Carcinoma NOS $^{a}$ metastatic ${ }^{b}$ & 0 & 1 & 0 \\
\hline Undetermined & 1 & 0 & 0 \\
\hline \multicolumn{4}{|c|}{ B6.129-Trp53 ${ }^{\mathrm{tm} 1 \mathrm{Brd}}$ Mice } \\
\hline Animals/group: & 25 & 31 & 35 \\
\hline Early Deaths: & $3(12 \%)$ & $4(13 \%)$ & $9(26 \%)$ \\
\hline \multicolumn{4}{|l|}{ Cause of Death: } \\
\hline Rhabdomyosarcoma & 0 & 1 & 3 \\
\hline Sarcoma & 1 & 2 & 1 \\
\hline Osteosarcoma & 1 & 0 & 0 \\
\hline Leiomyosarcoma & 0 & 0 & 1 \\
\hline Carcinosarcoma & 0 & 0 & 1 \\
\hline Histiocytic sarcoma & 0 & 0 & 1 \\
\hline Ulcerative dermatitis & 0 & 0 & 1 \\
\hline Nephropathy & 0 & 0 & 1 \\
\hline Undetermined & 1 & 1 & 0 \\
\hline \multicolumn{4}{|c|}{$\begin{array}{l}\text { Formaldehyde exposure had no statistically significant effect on survival of either mouse strain. Nin } \\
\text { mice died or were euthanized early primarily due to the presence of large or ulcerated osteosarcomas } \\
\text { B6.129-Trp53 }{ }^{\text {tm1Brd }} \text { mice (16) were due to the presence of large sarcomas and rhabdomyosarcomas. } \\
\text { aNOS - not otherwise specified. } \\
\text { bCarcinoma in lung, primary site unknown. }\end{array}$} \\
\hline
\end{tabular}


Table 2. Hematological Parameters of C3B6.129F1-Trp53 ${ }^{\text {tm1Brd }}$ Mice Exposed to Formaldehyde

\begin{tabular}{|c|c|c|c|c|c|c|c|}
\hline \multicolumn{8}{|c|}{ Erythron } \\
\hline Formaldehyde & RBC & HgB & Hct & MCV & МСH & МСНС & Retics \\
\hline Concentration & $10^{6} / \mathrm{mL}$ & g/dL & $\%$ & fL & pg & g/dL & $10^{6} / \mu \mathrm{L}$ \\
\hline $0 \mathrm{ppm}$ & $9.45 \pm 0.52$ & $14.7 \pm 0.7$ & $46.7 \pm 2.2$ & $49.5 \pm 0.7$ & $15.6 \pm 0.3$ & $31.5 \pm 0.4$ & $0.29 \pm 0.05$ \\
\hline $7.5 \mathrm{ppm}$ & $9.29 \pm 1.08$ & $14.3 \pm 1.5$ & $45.4 \pm 4.6$ & $49.0 \pm 1.5$ & $15.4 \pm 0.5$ & $31.5 \pm 0.4$ & $0.32 \pm 0.12$ \\
\hline 15 ppm & $9.44 \pm 0.51$ & $14.7 \pm 0.8$ & $46.2 \pm 2.2$ & $49.0 \pm 0.8$ & $15.5 \pm 0.2$ & $31.7 \pm 0.5$ & $0.31 \pm 0.07$ \\
\hline \multicolumn{8}{|c|}{ Leukon } \\
\hline Formaldehyde & WBC & Neut & Lymph & Mono & Eos & Plts & \\
\hline Concentration & $10^{3} / \mu \mathrm{L}$ & $10^{3} / \mu \mathrm{L}$ & $10^{3} / \mu \mathrm{L}$ & $10^{3} / \mu \mathrm{L}$ & $10^{3} / \mu \mathrm{L}$ & $10^{3} / \mu \mathrm{L}$ & \\
\hline $0 \mathrm{ppm}$ & $5.07 \pm 1.40$ & $1.05+1.09$ & $3.67 \pm 0.86$ & $0.20 \pm 0.11$ & $0.13+0.10$ & $1312+214$ & \\
\hline $7.5 \mathrm{ppm}$ & $4.93 \pm 1.70$ & $1.13+0.94$ & $3.45 \pm 0.79$ & $0.21+0.14$ & $0.12 \pm 0.09$ & $1283+200$ & \\
\hline $15 \mathrm{ppm}$ & $4.37+0.79$ & $0.80+0.26$ & $3.23+0.57$ & $0.22+0.11$ & $0.12+0.04$ & $1209+121$ & \\
\hline
\end{tabular}

Formaldehyde exposure had no significant effect on any of the hematological parameters of C3B6.129F1-Trp53 ${ }^{\text {tm1Brd }}$ mice.

Table 3. Hematological Parameters of B6.129-Trp53 ${ }^{\text {tm1Brd }}$ Mice Exposed to Formaldehyde

\begin{tabular}{|c|c|c|c|c|c|c|c|}
\hline \multicolumn{8}{|c|}{ Erythron } \\
\hline Formaldehyde & RBC & HgB & Hct & MCV & МСH & МСHC & Retics \\
\hline Concentration & $10^{6} / \mathrm{mL}$ & g/dL & $\%$ & fL & pg & g/dL & $10^{6} / \mu \mathrm{L}$ \\
\hline $0 \mathrm{ppm}$ & $9.62 \pm 0.33$ & $14.0 \pm 0.5$ & $46.4 \pm 1.5$ & $48.3 \pm 0.9$ & $14.6 \pm 0.3$ & $30.2 \pm 0.4$ & $0.31 \pm 0.03$ \\
\hline $7.5 \mathrm{ppm}$ & $9.34 \pm 1.09$ & $13.6 \pm 1.9$ & $45.4 \pm 4.6$ & $48.8 \pm 2.2$ & $14.5 \pm 0.8$ & $29.7 \pm 2.1$ & $0.39 \pm 0.31$ \\
\hline $15 \mathrm{ppm}$ & $9.38 \pm 0.62$ & $13.7 \pm 0.8$ & $45.3 \pm 2.8$ & $48.3 \pm 0.9$ & $14.6 \pm 0.3$ & $30.3 \pm 0.6$ & $0.30 \pm 0.03$ \\
\hline \multicolumn{8}{|c|}{ Leukon } \\
\hline Formaldehyde & WBC & Neut & Lymph & Mono & Eos & Plts & \\
\hline Concentration & $10^{3} / \mu \mathrm{L}$ & $10^{3} / \mu \mathrm{L}$ & $10^{3} / \mu \mathrm{L}$ & $10^{3} / \mu \mathrm{L}$ & $10^{3} / \mu \mathrm{L}$ & $10^{3} / \mu \mathrm{L}$ & \\
\hline $0 \mathrm{ppm}$ & $5.4 \pm 1.8$ & $0.60 \pm .150$ & $4.44 \pm 0.77$ & $0.192 \pm 0.07$ & $0.127 \pm 0.03$ & $1409 \pm 182$ & \\
\hline $7.5 \mathrm{ppm}$ & $5.9 \pm 1.9$ & $0.97 \pm 1.49$ & $4.54 \pm 0.92$ & $0.220 \pm 0.08$ & $0.125 \pm 0.04$ & $1350 \pm 292$ & \\
\hline 15 ppm & $5.3 \pm 1.3$ & $0.62 \pm 0.29$ & $4.37 \pm 1.12$ & $0.172+0.07$ & $0.141+0.06$ & $1344+283$ & \\
\hline
\end{tabular}


Absence of Formaldehyde-Induced Neoplasia in Trp53 Haploinsufficient Mice Exposed by Inhalation

Table 4. Nasal Lesions in Trp53 $₫$ Mice Exposed to Formaldehyde

\begin{tabular}{|c|c|c|c|}
\hline Formaldehyde Concentration & 0 ppm & 7.5 ppm & 15 ppm \\
\hline \multicolumn{4}{|c|}{ C3B6.129F1-Trp53 ${ }^{\mathrm{tm1Brd}}$ Mice } \\
\hline \multicolumn{4}{|l|}{ Respiratory Epithelium } \\
\hline Squamous metaplasia & $0 / 21^{\mathrm{a}}$ & $14 / 21(1.2)^{\mathrm{b}}$ & $22 / 23(1.5)$ \\
\hline Hyperplasia & $0 / 21$ & $0 / 21$ & $1 / 23(1.0)$ \\
\hline \multicolumn{4}{|l|}{ Turbinate } \\
\hline Osteogenesis & $0 / 21$ & $0 / 21$ & 3/23 (3.0) \\
\hline \multicolumn{4}{|c|}{ B6.129-Trp53 ${ }^{\mathrm{tm} 1 \mathrm{Brd}}$ Mice } \\
\hline \multicolumn{4}{|l|}{ Respiratory Epithelium } \\
\hline Squamous metaplasia & $0 / 22$ & $13 / 27(1.0)$ & $17 / 26(1.5)$ \\
\hline \multicolumn{4}{|l|}{ Turbinate } \\
\hline Osteogenesis & $0 / 22$ & $1 / 27(1.0)$ & $1 / 26(1.0)$ \\
\hline
\end{tabular}

Mice were exposed to conditioned air, 7.5- or 15-ppm formaldehyde $6 \mathrm{hr} / \mathrm{d}$, 5d/wk for 8 wk and then held without further exposure for $32 \mathrm{wk}$.

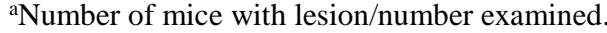

${ }^{\mathrm{b}}$ Average severity score based upon 1 = minimal, 2 = mild, 3 = moderate, 4 = marked.

Table 5. Neoplasms in C3B6.129F1-Trp53 ${ }^{\text {tm1Brd }}$ Mice Exposed to Formaldehyde

\begin{tabular}{lccc}
\hline Formaldehyde Concentration & $\mathbf{0 ~} \mathbf{~ p m}$ & $\mathbf{7 . 5} \mathbf{~ p p m}$ & $\mathbf{1 5} \mathbf{~ p p m}$ \\
\hline Number examined: & $\mathbf{2 5}$ & $\mathbf{2 4}$ & $\mathbf{2 5}$ \\
\hline Osteosarcoma & $4^{\mathrm{a}}(16 \%)^{\mathrm{b}}$ & $1(4.2 \%)$ & 0 \\
Sarcoma, NOS', stomach/rib cage & 0 & $1(4.2 \%)$ & 0 \\
Sarcoma, NOS, subcutis & $1(4 \%)$ & $1(4.2 \%)^{\mathrm{d}}$ & 0 \\
Sarcoma, NOS & 0 & 0 & $1(4 \%)$ \\
Sarcoma, NOS, Harderian gland & 0 & $1(4.2 \%)$ & 0 \\
Hepatocellular adenoma & $5(20 \%)$ & $4(16.7 \%)$ & $1(4 \%)$ \\
Hepatocellular carcinoma & 0 & $2(8.3 \%)$ & 0 \\
Alveolar/bronchiolar carcinoma & $1(4 \%)$ & 0 & 0 \\
Hemangiosarcoma, subcutis & 0 & $1(4.2 \%)^{\mathrm{d}}$ & 0 \\
Lymphoma & 0 & $1(4.2 \%)$ & $2(8 \%)$ \\
\hline
\end{tabular}

Mice were exposed to conditioned air, 7.5- or 15-ppm formaldehyde $6 \mathrm{hr} / \mathrm{d}, 5 \mathrm{~d} / \mathrm{wk}$ for $8 \mathrm{wk}$ and then held without further exposure for $32 \mathrm{wk}$.

${ }^{a}$ Number of mice with lesion (includes animals that died early).

bercentage of animals with lesion.

'Not otherwise specified.

${ }^{\mathrm{d}}$ Sarcoma and hemangiosarcoma present in same animal.

eTissue undetermined. 
Absence of Formaldehyde-Induced Neoplasia in Trp53 Haploinsufficient Mice Exposed by Inhalation

Table 6. Neoplasms in B6.129-Trp53 ${ }^{\text {tm1Brd }}$ Mice Exposed to Formaldehyde

\begin{tabular}{lccc}
\hline Formaldehyde Concentration & $\mathbf{0 ~} \mathbf{~ p m}$ & $\mathbf{7 . 5} \mathbf{~ p p m}$ & $\mathbf{1 5} \mathbf{~ p p m}$ \\
\hline Number Examined: & $\mathbf{2 5}$ & $\mathbf{3 1}$ & $\mathbf{3 5}$ \\
\hline Osteosarcoma & $1^{\mathrm{a}}(4.0 \%)^{\mathrm{b}}$ & 0 & 0 \\
Hepatocellular adenoma & $2(8.0 \%)$ & 0 & 0 \\
Alveolar/bronchiolar adenoma & $1(4.0 \%)$ & 0 & 0 \\
Histiocytic sarcoma & 0 & $1(3.2 \%)$ & $2(5.7 \%)$ \\
Lymphoma & 0 & $1(3.2 \%)$ & $1(2.9 \%)$ \\
Rhabdomyosarcoma & $0^{*}$ & $1(3.2 \%)$ & $4(11.4 \%)$ \\
Leiomyosarcoma, subcutis & 0 & 0 & $1(2.9 \%)$ \\
Carcinosarcoma, subcutis & 0 & 0 & $1(2.9 \%)$ \\
Sarcoma, NOSc, subcutis & $1(4.0 \%)$ & $3(9.7 \%)$ & $1(2.9 \%)$ \\
\hline
\end{tabular}

Mice were exposed to conditioned air, 7.5- or 15-ppm formaldehyde $6 \mathrm{hr} / \mathrm{d}, 5 \mathrm{~d} / \mathrm{wk}$ for $8 \mathrm{wk}$ and then held without further exposure for $32 \mathrm{wk}$.

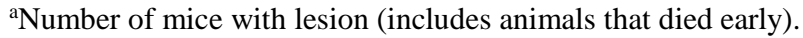

bPercentage of animals with lesion.

'Not otherwise specified.

*Significant trend $(\mathrm{p}<0.05)$. 


\section{C3B6.129F1-Trp53 ${ }^{\text {tm1Brd }}$ Mice}

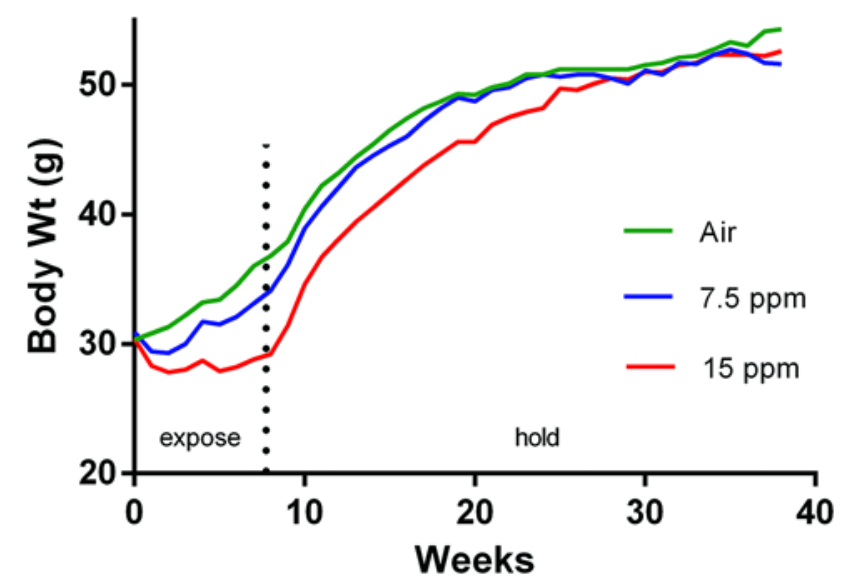

\section{B6.129-Trp53 ${ }^{\text {tm1Brd }}$ Mice}

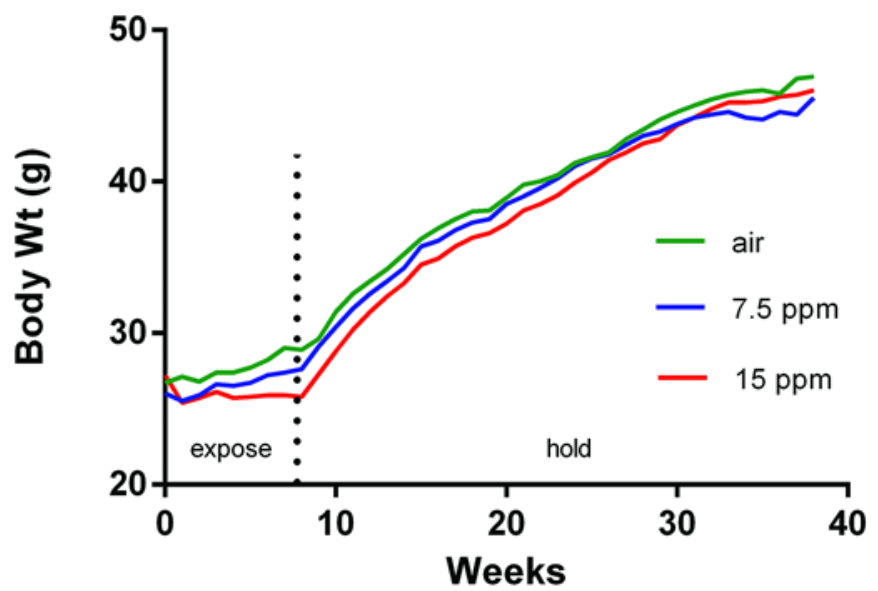

Figure 1. Body Weights of Trp53 $3^{ \pm}$Mice Exposed to Formaldehyde

C3B6.129F1-Trp53 ${ }^{\mathrm{tm} 1 \mathrm{Brd}}$ and B6.129-Trp53 ${ }^{\mathrm{tm} 1 \mathrm{Brd}}$ mice were exposed to formaldehyde at 0 (air), 7.5, or 15 ppm for 8 weeks, and then held for 32 weeks without exposure. (A) Body weights of C3B6F1.129-Trp53 ${ }^{\text {tm1Brd }}$ mice exposed to 7.5-ppm formaldehyde were significantly less than controls $(\mathrm{p}<0.05)$ from week 1 to week 11 and at weeks 37 and 38. Body weights of mice exposed to 15-ppm formaldehyde were significantly less than controls $(\mathrm{p}<0.05)$ from week 1 to week 24 and at weeks 37 and 38 .

(B) Body weights of B6.129-Trp53 ${ }^{\text {tm1Brd }}$ mice exposed to formaldehyde were not significantly different from controls at any time point. 
Formaldehyde

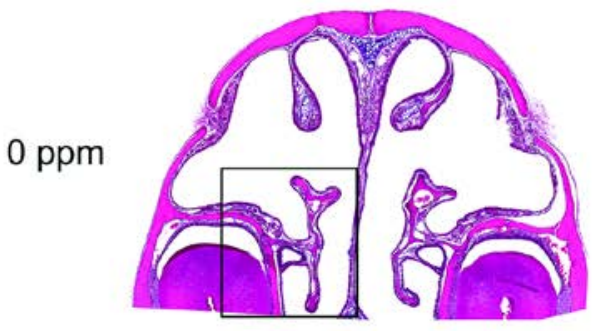

A

$15 \mathrm{ppm}$

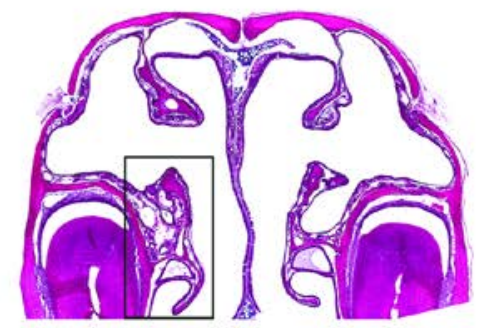

D
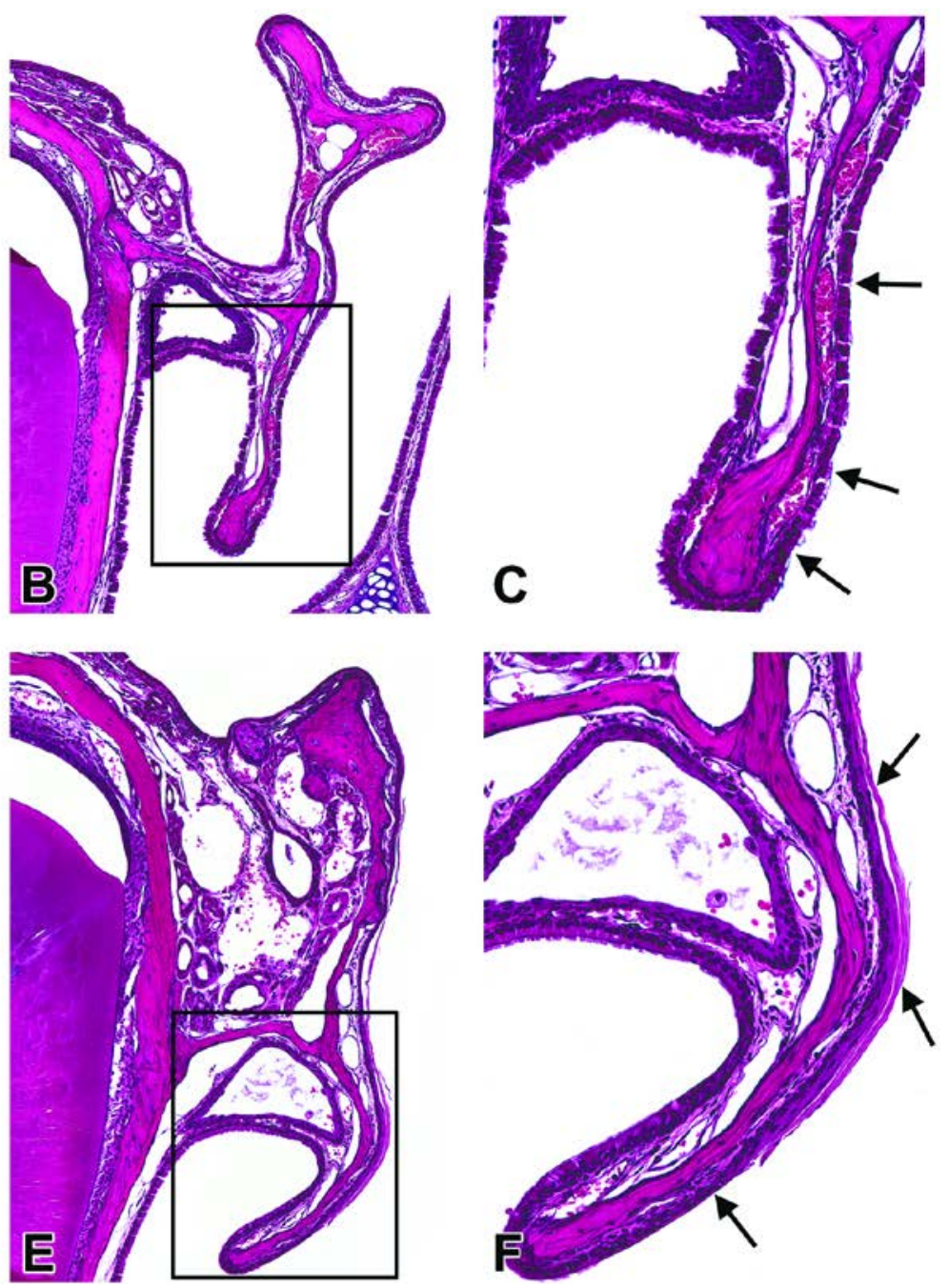

Figure 2. Squamous Metaplasia of the Nasal Cavity in Mice Exposed to Formaldehyde

(A) A low magnification showing the location of the maxilloturbinates (within the box) and the nasoturbinates located dorsally and attached to the roof of the nasal cavity on either side of the nasal septum, Level 1. (B, C) Higher magnifications of the maxilloturbinate (within the box) showing the normal respiratory epithelium covering the turbinate bones. The normal respiratory epithelium in this area consists of a single layer of ciliated, columnar, and non-ciliated cuboidal cells (arrows in C).

(D, E, F) Level I section of the nasal cavity from a high-dose (15-ppm) animal. As in A, panel D is a low magnification showing the location of the maxilloturbinates (within the box) and the nasoturbinates dorsally. $\mathrm{E}$ and $\mathrm{F}$ are higher magnifications of the affected turbinate epithelium (within the box). The normal respiratory epithelium has been replaced by keratinized, stratified squamous epithelium (arrows in panel F). 

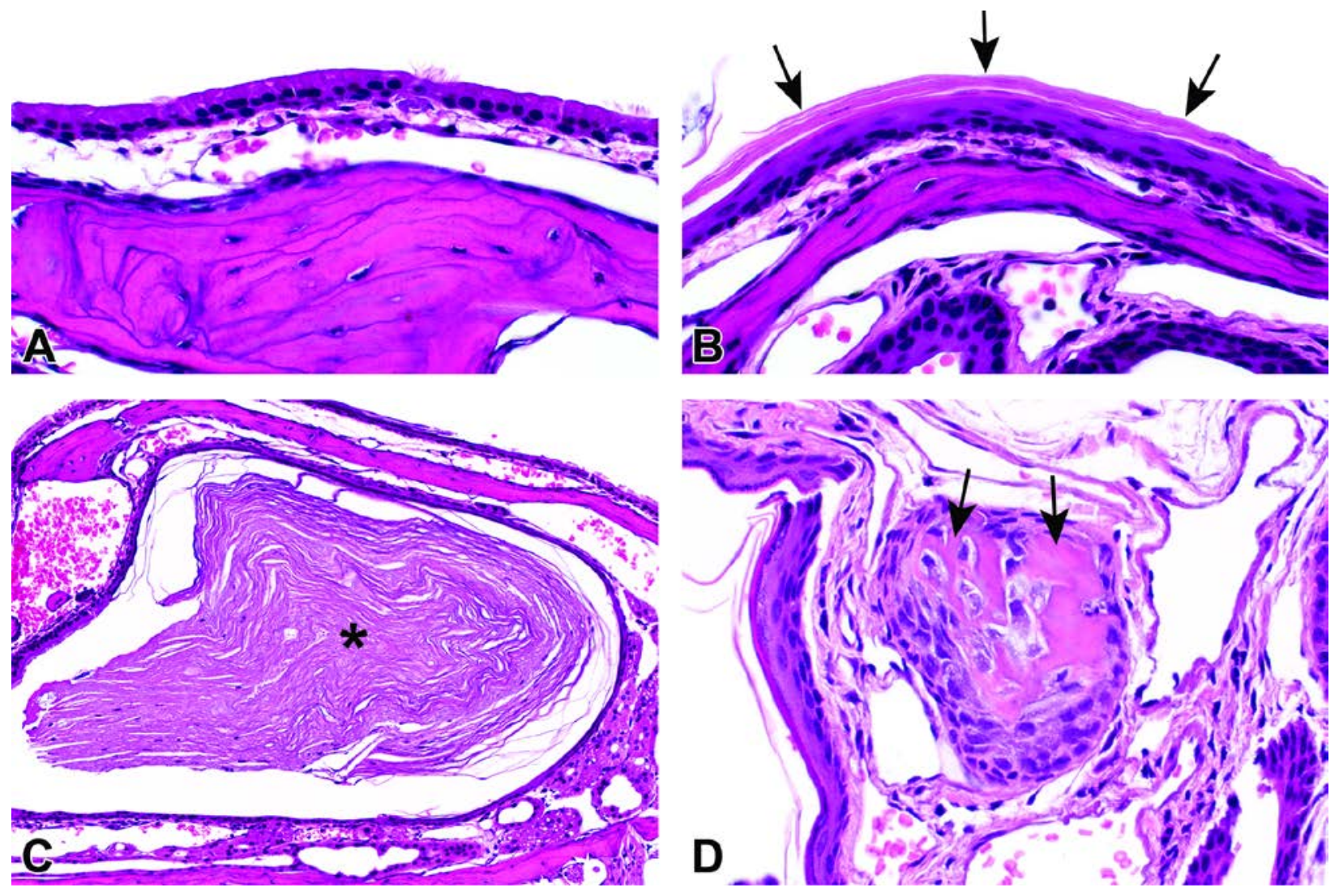

\section{Figure 3. Keratin Accumulation and Osteogenesis in Nasal Cavity of Mice Exposed to Formaldehyde}

C3B6.129F1-Trp5 ${ }^{\mathrm{tm} 1 \mathrm{Brd}}$ and B6.129-Trp53 ${ }^{\mathrm{tm} 1 \mathrm{Brd}}$ mice were exposed to formaldehyde at 0 (air), 7.5, or 15 ppm for 8 weeks, and then held for 32 weeks without exposure. Significant lesions were still present in the nasal cavity of both mouse strains when examined 32 weeks after formaldehyde exposure. (A) Normal appearing respiratory epithelium on the nasal turbinate of an airexposed control C3B6.129F1-Trp53 ${ }^{\mathrm{tm} 1 \mathrm{Brd}}$ mouse. H\&E, 60x. (B) Squamous metaplasia of respiratory epithelium on the nasal turbinate of a C3B6.129F1-Trp53 ${ }^{\mathrm{tm} 1 \mathrm{Brd}}$ mouse exposed to 15-ppm formaldehyde. Note multiple layers of keratin (arrows). H\&E, 60x. (C) In some animals exposed to 15-ppm formaldehyde, accumulated keratin was present in the space behind a turbinate scroll and, in some cases, filled the space behind the scroll (asterisk). H\&E, 20x. (D) Minimal osteogenesis of the nasoturbinate was present in a few mice exposed to 15-ppm formaldehyde. The lesion consisted of a small focus within the lamina propria consisting of eosinophilic osteoid containing numerous large plump osteoblast nuclei (arrows). H\&E, 60x. 

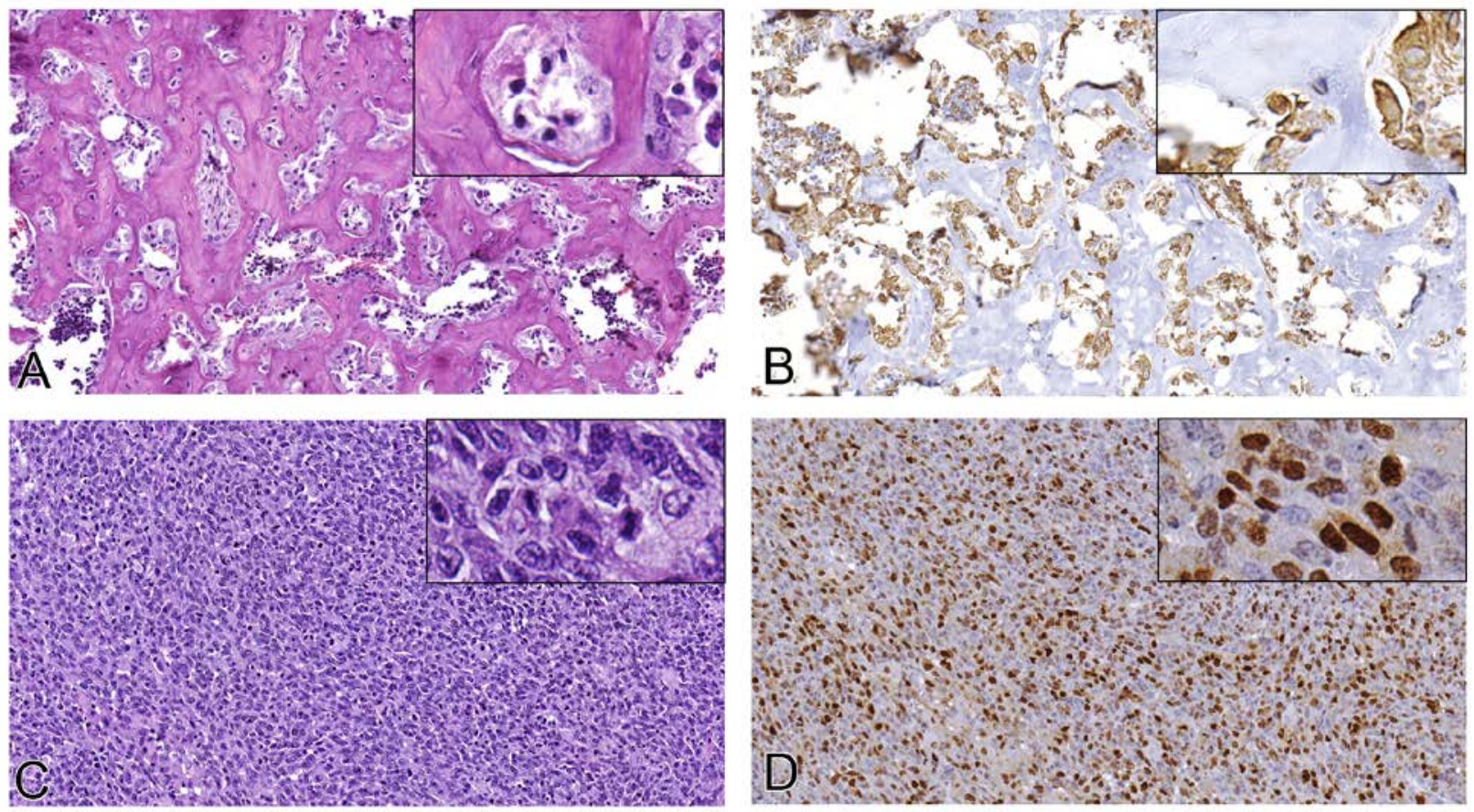

Figure 4. Neoplastic Lesions in Trp53 Mice Exposed to Formaldehyde

Histological appearance (A, C); hematoxylin and eosin, and immunohistochemical staining with vimentin (B) and myogenin (D) of tumors in C3B6.129F1-Trp53 $3^{\mathrm{tm} 1 \mathrm{Brd}}$ mice and B6.129-Trp53 ${ }^{\mathrm{tm} 1 \mathrm{Brd}}$ mice. (A) Osteosarcoma in a C3B6.129F1-Trp53 ${ }^{\text {tm1Brd }}$ mouse, characterized by formation of irregular bone trabeculae and adjacent highly pleomorphic neoplastic spindle-shaped cells. Inset: Higher magnification of pleomorphic neoplastic cell types adjacent to bone trabeculae. (B) Vimentin-stained section of osteosarcoma shown in (A). Note pleomorphic neoplastic cells with cytoplasmic expression of vimentin, an intermediate filament typically present in non-epithelial cells. Inset: Higher magnification of pleomorphic neoplastic cell types with positively staining cytoplasm. (C) Rhabdomyosarcoma in a B6.129-Trp53 ${ }^{\text {tm1Brd }}$ mouse, characterized by pleomorphic cells with varying amounts of cytoplasm and oval-to-elongated nuclei. Inset: Higher magnification of tumor cells showing oval-to-elongated nuclei, abundant cytoplasm, and mitotic activity. (D) Myogenin-stained section of rhabdomyosarcoma shown in (C). Note variably sized pleomorphic tumor cells with nuclear expression of myogenin, a transcription factor essential for skeletal muscle development and repair. Inset: Higher magnification of pleomorphic tumor cells showing positively staining oval and elongated nuclei. 
Absence of Formaldehyde-Induced Neoplasia in Trp53 Haploinsufficient Mice Exposed by Inhalation

\section{Appendix A Supplemental Material}

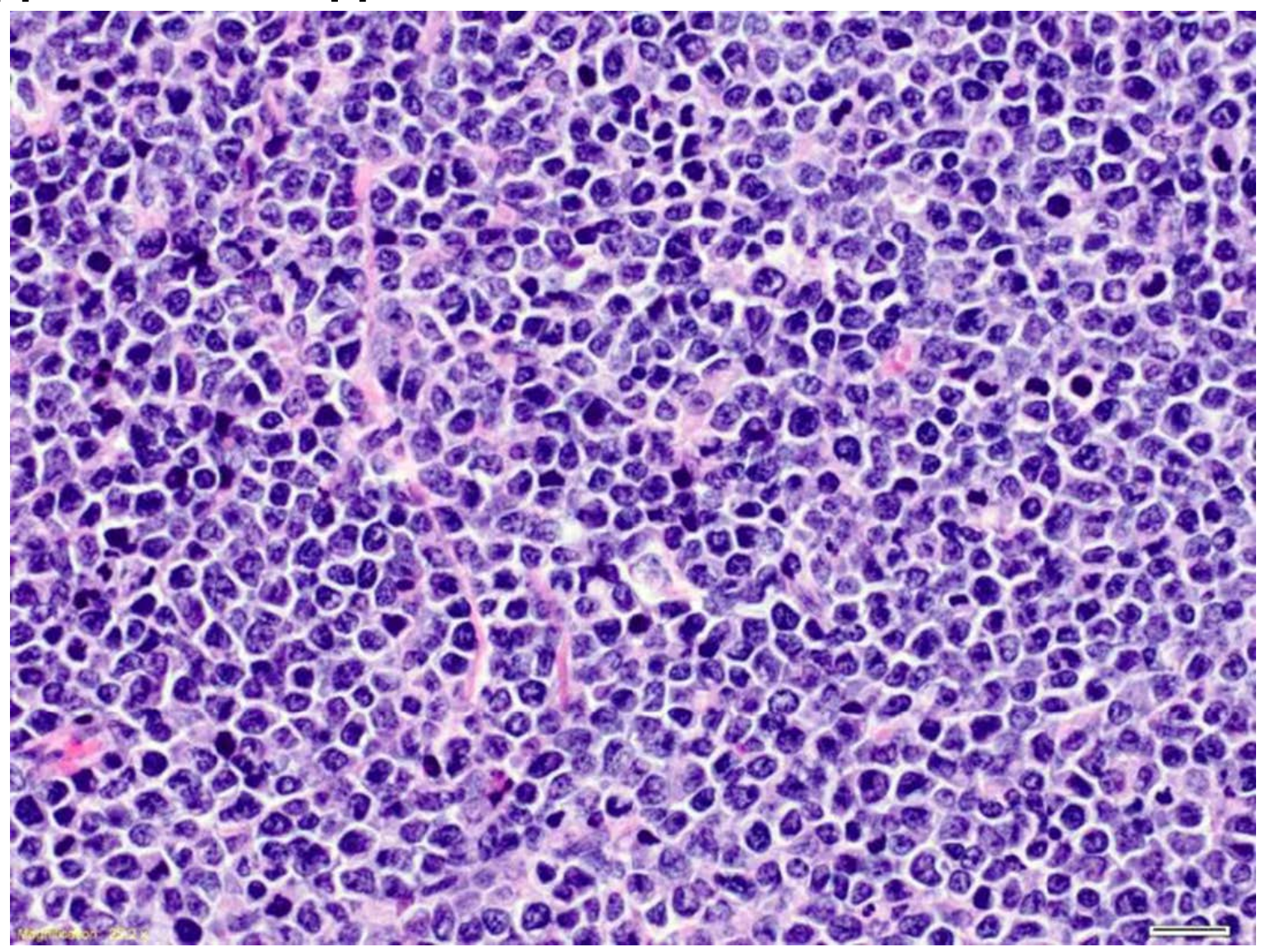

Figure A-1. Thymus, Cortex, Lymphoma of C3B6.129F1-Trp53 ${ }^{\text {tm1Brd }}$ Mice Exposed to Formaldehyde

The lymphomas appeared as diffuse sheets of relatively large lymphocytes with large, moderately pleomorphic basophilic, granular nuclei with one or more prominent nucleoli and a scant amount of eosinophilic cytoplasm. H\&E, 40X. 


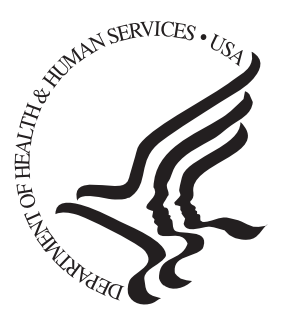

\section{National Toxicology Program}

NTP Central Data Managment, MD K2-05

National Insitute of Enviromental Health Sciences

P.O. Box 12233

Research Triangle Park, NC 27709

http://ntp.niehs.nih.gov 